\title{
Two new species of Dendrophthora (Viscaceae) from the Venezuelan Andes
}

\author{
Daniela S. Canelón', Santos M. Niño', \\ Laurence J. Dorr², Marcos A. Caraballo-Ortiz ${ }^{2}$
}

I BioCentro-UNELLEZ, Herbario PORT, Mesa de Cavacas, Guanare, estado Portuguesa, Venezuela 2 Department of Botany, MRC-166, National Museum of Natural History, Smithsonian Institution, P.O. Box 37012, Washington, D.C. 22013-7012, USA

Corresponding author: Daniela S. Canelón (canelonbarraezdaniela@gmail.com)

Academic editor: D. Nickrent | Received 27 November 2019 | Accepted 16 January 2020 | Published 7 February 2020

Citation: Canelón DS, Niño SM, Dorr LJ, Caraballo-Ortiz MA (2020) Two new species of Dendrophthora (Viscaceae) from the Venezuelan Andes. PhytoKeys 140: 1-10. https://doi.org/10.3897/phytokeys.140.48865

\begin{abstract}
Two new species of Dendrophthora Eichler (Viscaceae) from northwestern Venezuela are described and illustrated. Both mistletoes, D. apiculata Canelón et al., sp. nov. and D. coronata Canelón et al., sp. nov., are confined to subpáramo and páramo ecosystems of the Venezuelan Andes and are, at present, only known from Guaramacal National Park (Portuguesa and Trujillo states). Ecological aspects and possible taxonomic affinities are discussed. A distribution map also is presented.
\end{abstract}

\section{Resumen}

Se describen e ilustran dos nuevas especies de Dendrophthora Eichler (Viscaceae) del noroeste de Venezuela. Ambos muérdagos, D. apiculata Canelón et al., sp. nov. y D. coronata Canelón et al., sp. nov., se limitan a los ecosistemas subpáramo y páramo de los Andes venezolanos y, en la actualidad, solo se conocen en el Parque Nacional Guaramacal (estados Portuguesa y Trujillo). Se discuten aspectos ecológicos y posibles afinidades taxonómicas. También se presenta un mapa de distribución.

\section{Keywords}

Flora of Venezuela, Guaramacal National Park, Mistletoe, Muérdago, Páramo, Parque Nacional Guaramacal, Subpáramo 


\section{Introduction}

Dendrophthora Eichler (Viscaceae) is the second most diverse genus of mistletoe in the New World comprising over 125 species distributed in Mexico, Central and South America, and the Caribbean (Nickrent in press). We follow Nickrent et al. (2010, 2019) in placing Dendropthora in the Viscaceae, even though Stevens (2020) places the genus in a more broadly construed Santalaceae (tribe Visceae Horan.). In South America, the vast majority of Dendrophthora species are found at high elevations along the Cordillera de los Andes, ranging from Colombia and Venezuela south to Ecuador, Peru, and Bolivia (Kuijt 1961). Approximately 28 species of Dendrophthora have been reported from Venezuela, including 13 endemic species (Rizzini 1982, Kuijt 2008, Tropicos 2019). For Guaramacal National Park, which is located in the northeastern portion of the Venezuelan Andes (Portuguesa and Trujillo states, Fig. 1), Dorr et al. (2000) reported three species of Dendrophthora: D. ambigua Kuijt, D. elliptica (Gardner) Krug \& Urb. and an unidentified species. Continued research and collection, focusing on the flora of Guaramacal National Park, revealed an additional unidentified species. Inasmuch as both unnamed species do not match any previously published description of Dendrophthora found in the Andes of Venezuela or in the rest of the Americas, we describe them as new and provide information on their

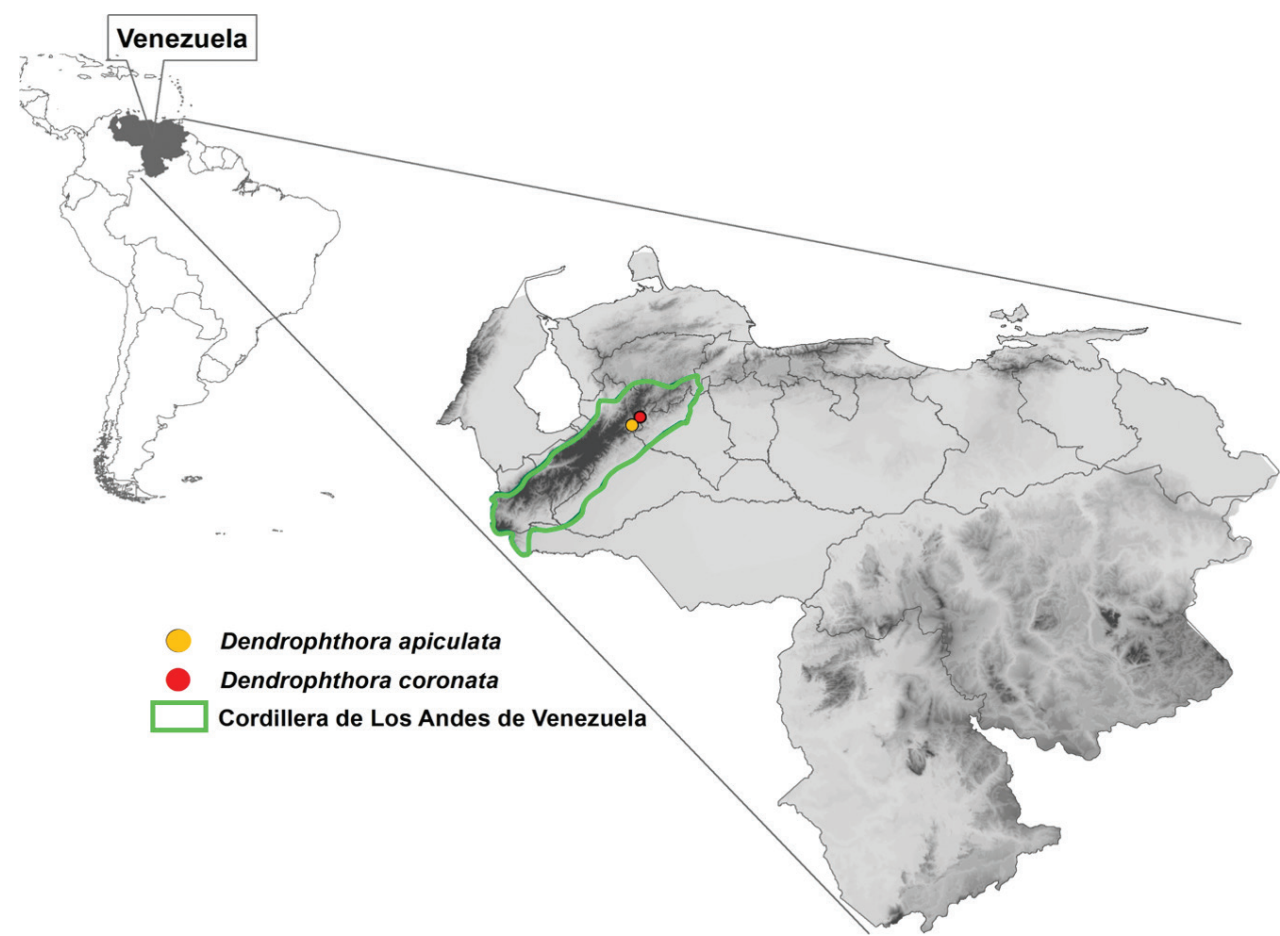

Figure I. Distribution of Dendrophthora apiculata and D. coronata in the Andes of Venezuela. (Source: Centro Cartográfico, UNELLEZ-VPA, 2019). 
habitats and known hosts. Both species apparently are restricted to the subpáramo and páramo ecosystems of the Venezuelan Andes and are, at present, only known from Guaramacal National Park.

\section{Materials and methods}

We studied herbarium specimens of Dendrophthora collected in the Venezuelan Andes and deposited in the following herbaria: PORT (Portuguesa, Venezuela) and US (Smithsonian Institution). We also examined the type collection of the latter herbarium, examined specimens in COL (Universidad Nacional de Colombia herbarium, Bogotá, Colombia), and accessed specimens at $\mathrm{MO}$ (Missouri Botanical Garden) via the Global Plants JSTOR (2019) and Tropicos (2019) online portals. We also exhaustively reviewed the many articles, monographs, and checklists treating Dendrophthora published by Kuijt $(1961,2000,2003,2008,2011,2016)$ and our terminology follows his.

Species descriptions were made combining information from fresh and dried specimens, with inflorescences and flowers rehydrated using Aerosol OT solution (Ayensu 1967).

\section{Taxonomic treatment}

\section{Dendrophthora apiculata Canelón, S.M.Nińo, Dorr \& Caraballo, sp. nov. urn:Isid:ipni.org:names:77205497-1}

Figures 2, 3

Type. Venezuela. Trujillo: Municipio Boconó, Parque Nacional Guaramacal, Páramo de Guaramacal, from summit of Boconó-Caserío de Guaramacal road to the television towers, 2900-3100 m, 13 June 2001, L.J. Dorr 8953, with B. Stergios \& S.M. Niño (holotype: PORT!; isotypes: K, MO, US-00662868!).

Diagnosis. Dendrophthora apiculata is distinguished from congeners by its rough striate stems; minute, ca. $0.5 \mathrm{~mm}$ long cataphylls surrounding all nodes; leaf blades 5-20 × 3-6 mm, apex apiculate with an apiculum $0.2-0.5 \mathrm{~mm}$ long; inflorescences usually $1(2)$ per leaf axil, staminate inflorescences triseriate and pistillate ones uniseriate; flowers ca. $1 \mathrm{~mm}$ long; and mature fruits globose-compressed, ca. 0.8-2 × 2-3 mm when dried.

Description. Aerial parasitic shrubs, monoecious; yellowish-green when fresh and drying dark brown. Stems woody; erect branches $20-30+\mathrm{cm}$ long; mature nodes at 2-3 cm long intervals, dichotomous, with multiple branches; coarse, longitudinal striations along principal branches with some transversal striations in basal branches (striations not visible in distal branchlets), minute papillose trichomes dispersed or absent; some lenticels present; cataphylls at nodes ca. $0.5 \mathrm{~mm}$ long. Leaves opposite, coriaceous; petioles winged, $2-5 \mathrm{~mm}$ long, indistinct; blades obovate, $5-20 \times 3-6 \mathrm{~mm}$, base cuneate, apex apiculate with an apiculum $0.2-0.5 \mathrm{~mm}$ long, margin entire; 


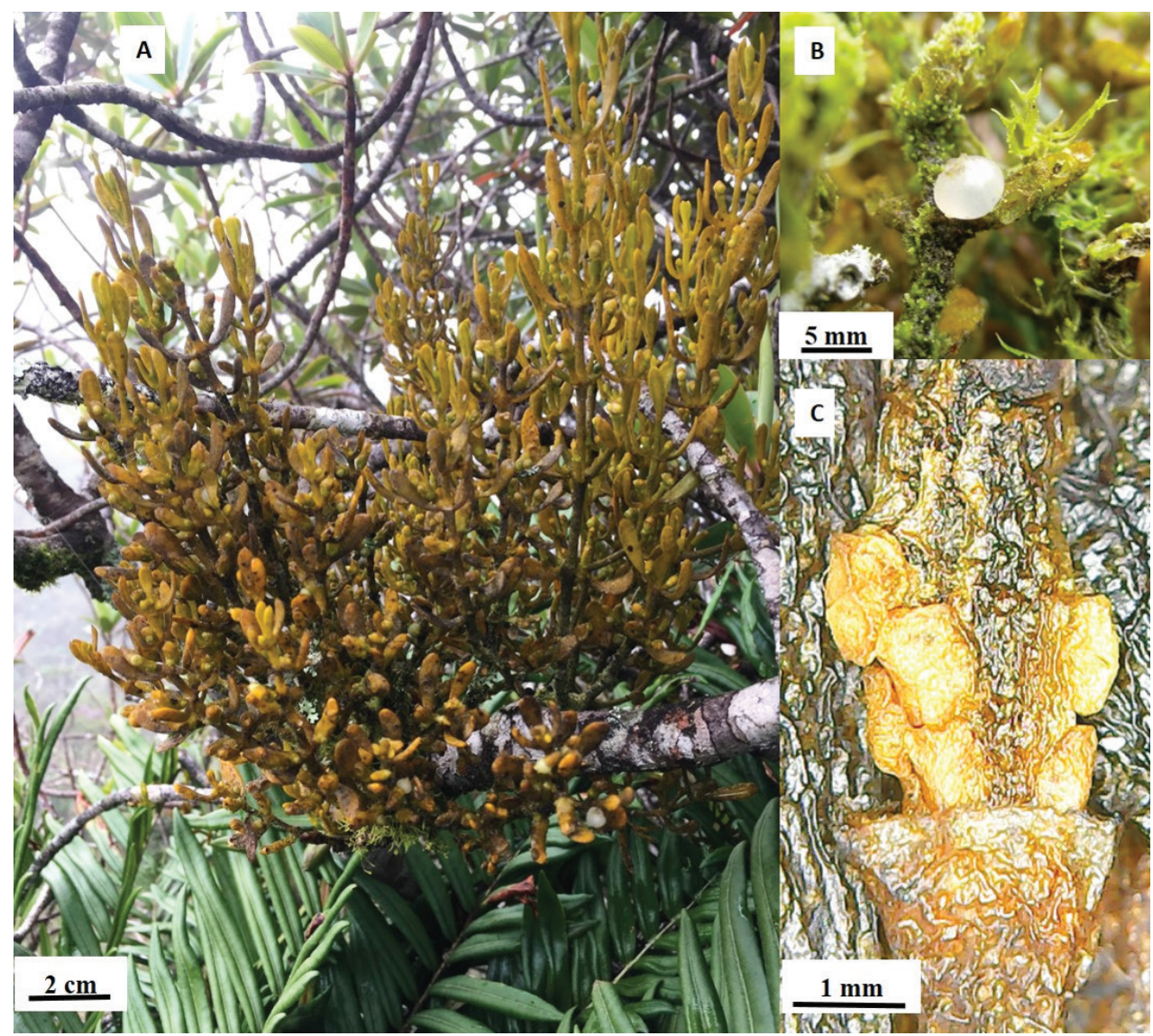

Figure 2. Dendrophthora apiculata. A Habit B fruit C basal flowers (staminate) (Photograph: D. Canelón).

veins reticulate with midvein evident on the adaxial side when fresh and inconspicuous when dried. Pistillate and staminate inflorescences separate, alternate on the same branch or branches either predominantly staminate or predominantly pistillate, usually 1 inflorescence per leaf axil, sometimes 2; fertile internodes usually 1(2), 7-18 mm long; staminate inflorescences triseriate; peduncles simple, 1-3 mm long, rugose; cup subtending inflorescence $1.5-1.8 \times 2-2.5 \mathrm{~mm}$, edge of cup papillose; basal portion of staminate inflorescences with 9-12 flowers per segment (see Fig. 2C); flowers ca. $1 \mathrm{~mm}$ in diameter; embedded in an alveolus (sunken receptacle), emerging up to 2/3 during anthesis; pistillate inflorescences uniseriate; peduncles simple, 2-4 mm long, rugose; cup (sensu Kuijt) subtending inflorescence $0.8-1 \times 1-2.5 \mathrm{~mm}$, edge of cup papillose, with 3-5 flowers per segment, sometimes more (Fig. 3), flowers adjacent (sometimes touching each other); petals 3(4), triangular, glabrous. Fruits globose-compressed, ca. $0.8-2 \times 2-3 \mathrm{~mm}$ when dried, ripening white-translucent, crowned by persistent petals.

Distribution and hosts. Dendrophthora apiculata is known only from Guaramacal National Park (Trujillo state) between 2600-3100 m on both its northeastern and 


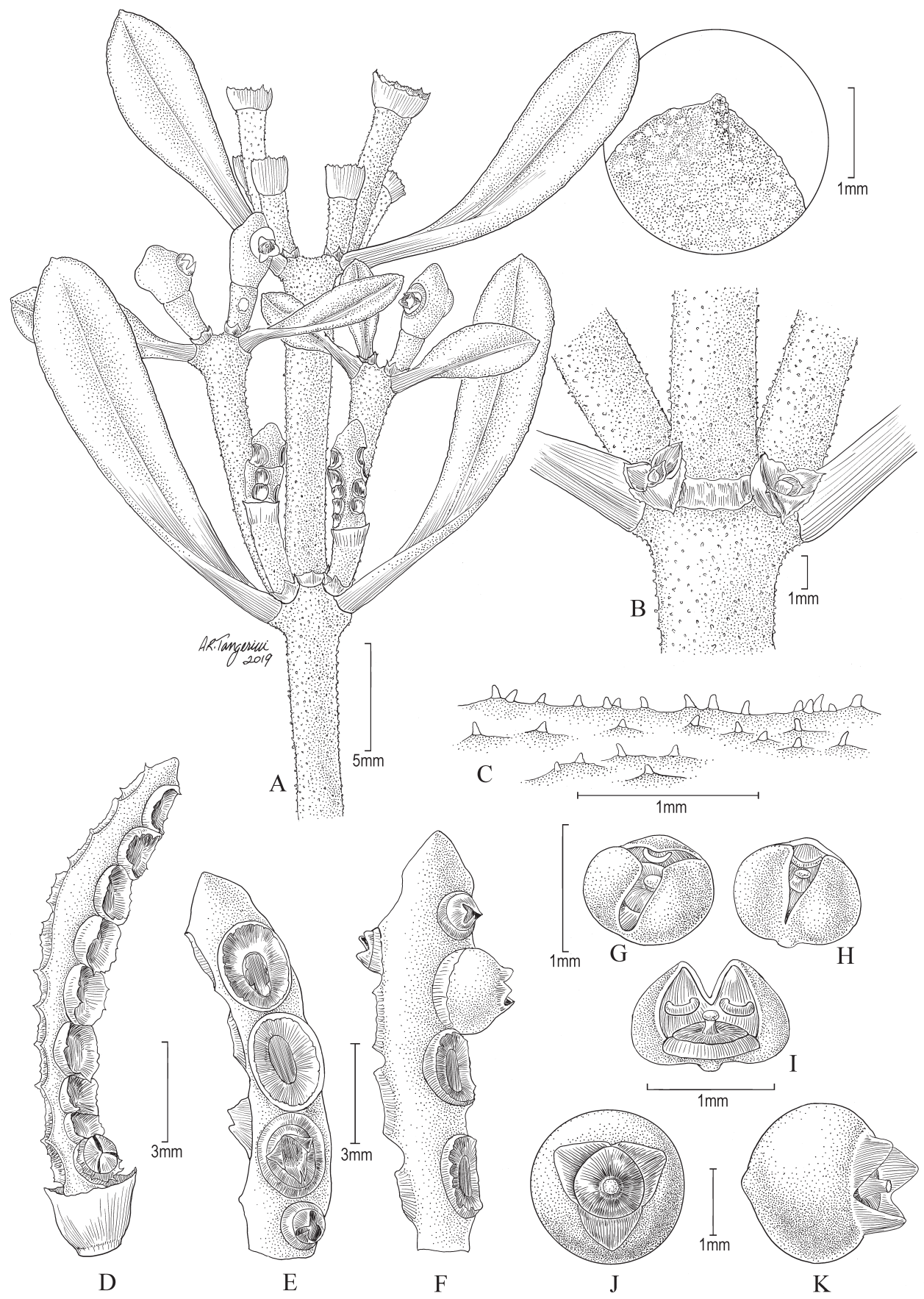

Figure 3. Dendrophthora apiculata. A Terminal branches showing inflorescences and leaves, including an enlargement of a leaf apex showing the apiculum (striations are not visible in these terminal branches) B Cataphylls at the base of a node C Papillose indumentum D-F Segments of pistillate inflorescences G-I Pistillate flowers J, K Mature fruits. (Source: Stergios et al. 20126, US). 
southwestern mountain slopes. This mistletoe grows in open areas of the páramo and evidently is uncommon throughout its distributional range. Its host range seems to be limited, as the only hosts recorded so far are the shrubs Cybianthus marginatus (Benth.) Pipoly (Primulaceae), Hypericum juniperinum Kunth (Hypericaceae), and Espeletia griffinii Ruiz-Teran \& López-Fig. (Asteraceae). Interestingly, the mistletoes found so far on the first host listed were observed on lower and middle branches, while in the last one they were found at the tips of branches.

Phenology. Reproductive individuals of Dendrophthora apiculata have been observed with flowers and fruits all year round, and the fruits seem to be an important source of food for the bird fauna present in the páramo and subpáramo habitats.

Etymology. The specific epithet is derived from "apiculate," which describes the minute sharp apiculum observed at the apex of leaves.

Discussion. Dendrophthora apiculata is similar to D. lindeniana Tiegh., but the latter has stems up to $1 \mathrm{~m}$ long, dense papillose trichomes covering the entire plant, leaves with rounded apices with papillose edges, and the cup subtending the inflorescence is usually bifid. In contrast, $D$. apiculata has stems up to $40 \mathrm{~cm}$ long, coarsely striate stems with scarce papillose indumentum or papillae absent; leaves with a smooth margin and a persistent, minute apiculum $0.2-0.5 \mathrm{~mm}$ long at the apex; and a cup subtending the inflorescence that is usually whole (or rarely rounded).

Regarding their distributions, Dendrophthora apiculata is found in the Páramo de Vicuyal (ca. $2730 \mathrm{~m}$ ) in Guaramacal National Park (Trujillo state), while D. lindeniana grows in the Páramo de Portachuelo $(2860 \mathrm{~m}$ ) (Táchira state), near the border with Colombia. The known localities for these two species are separated one from the other by ca. $240 \mathrm{~km}$.

Additional specimens examined. Venezuela. Trujillo: Municipio Boconó, Páramo de Guaramacal, SE of Boconó, 09 ${ }^{\circ} 10-14^{\prime} \mathrm{N}, 70^{\circ} 11-15^{\prime} \mathrm{W}, 2600-3100 \mathrm{~m}, 18$ July 1990, L.J. Dorr, L.C. Barnett, W. Diaz, G. Aymard, F. Ortega \& N. Murakami 7377 (NY, PORT); Carretera de tierra vía hacia las antenas, $09^{\circ} 14^{\prime} 29.0^{\prime \prime} \mathrm{N}, 70^{\circ} 11^{\prime} 65.0^{\prime \prime} \mathrm{W}, 2800 \mathrm{~m}$, 23 Sep. 2000, M. Niño, A. Licata \& L. Linárez 1385 (US); Sector El Campamento, UTM: 19 368148-1022056 [9.244052N, -70.200324W], 2600 m, 13 Apr. 2019, S. Niño \& D. Canelón 6112 (PORT, US); Páramo de Guaramacal, 3000-3100+ m, July 2002, B. Stergios \& R. Caracas 19754 (PORT, US-00728477); Parque Nacional Guaramacal, Páramo Vicuyal, UTM: 1014040 N, 362685 E [9.171395N, -70.249794W], 2730 m, 11 Apr. 2003, B. Stergios, L.J. Dorr, S.M. Niño \& R. Caracas 20126 (PORT, US-00728399).

\section{Dendrophthora coronata Canelón, S.M.Nińo, Dorr \& Caraballo, sp. nov. urn:Isid:ipni.org:names:77205498-1}

Figure 4

Type. Venezuela. Trujillo: Municipio Boconó, Parque Nacional Guaramacal, trail from antennas on the summit of Páramo de Guaramacal, NE to Fila Los Recostaderos [sic, Recortaderos] (UTM: 19 369344E, 1023140N) [9.253891N, -70.189471W], 
páramo and subpáramo vegetation, 2677-3100 m, 14 June 2001, L.J. Dorr 8988 with S.M. Niño \& R. Caracas (holotype: US-00662772!; isotype: PORT).

Diagnosis. Dendrophthora coronata is distinguished from congeners by its stems and young branches with longitudinal parallel striations; coroniform trichomes (i.e., papillae crowned by 2-6 minute, simple hairs) covering the entire plant; small, ca. $0.5 \times 1 \mathrm{~mm}$ cataphylls present at all nodes and sometimes found $1-2 \mathrm{~cm}$ above nodes on older branches; petioles $0.5-1 \mathrm{~mm}$ long, leaf blades $1-1.5 \times 1-1.2 \mathrm{~cm}$, apex rounded and margin slightly crenulate and papillose; uniseriate inflorescences with 5-9 flowers per series; and fruits globose-compressed, 2-3 $\times 2 \mathrm{~mm}$ when mature, white.

Description. Aerial parasitic shrubs, monoecious; yellow-orange when fresh, drying blackish or dark green. Stems woody, with multiple branches, 30-45 cm long, terete, surface coarse with parallel striations, with a dense layer of coroniform trichomes covering the entire plant; mature nodes separated by $2-3.5 \mathrm{~cm}$ long intervals, dichotomous; cataphylls $0.5-1 \mathrm{~mm}$ long at nodes, found $1-2 \mathrm{~cm}$ above nodes as branches became older. Leaves opposite, coriaceous; petioles flattened, 0.5-2 mm long; blades orbicular to elliptic, $1-1.5 \times 1-1.2 \mathrm{~cm}$, base slightly cuneate, apex rounded, margin indistinctly crenulate and papillose, surface rough on both sides, veins obscure in dry leaves (Fig. 4). Inflorescences completely pistillate within a branch, occasionally with staminate flowers at the base of the inflorescence (completely staminate inflorescences not seen); 1 per leaf axil, 1-3 fertile segments, each 4-10 mm long, uniseriate, greenish when dry; peduncles simple, 6-9 mm long, cup subtending inflorescence $1-1.5 \times$ 3-3.5 mm, almost always forked with a papillate apical edge. Flowers 3-9 per segment, 1-1.4 $\times 0.7-1 \mathrm{~mm}$. Fruits globose-compressed, 2-3 $2 \mathrm{~mm}$, ripening white- or purplish-translucent, surface granulose, tip protruding and crowned with persistent petals.

Distribution and habitat. This species has been found in the transition between cloud forest and subpáramo in Guaramcal. This vegetation is influenced by multiple factors including high rainfall $(3200+\mathrm{mm} /$ year $)$, elevation above sea level $(2400$ $3100 \mathrm{~m}$ ), as well as relative humidity (100\% for most of the year) (Cuello and Cleef 2011). Dendrophthora coronata is found in these Andean/high Andean forests characterized by woody vegetation of low stature with numerous individual shrubs and small trees, and a thin understory with a carpet of thick leaf litter. The canopy can reach between 6-14 m tall, with some emerging trees that reach $16 \mathrm{~m}$, among them: Ilex guaramacalensis Cuello \& Aymard (Aquifoliaceae), Miconia jahnii Pittier (Melastomataceae), Myrsine dependens (Ruiz \& Pav.) Spreng. (Primulaceae), and Symplocos tamana Steyerm. (Symplocaceae) (Cuello and Cleef 2011).

Phenology. As with most other species of tropical mistletoe, Dendrophthora coronata can be observed bearing flowers and fruits throughout the year. Its white fleshy fruits seem to be an important food source for forest birds.

Etymology. The species name is derived from the coroniform trichomes (i.e., papillae crowned by 2-6 minute, simple hairs) that cover the entire plant and that resemble small crowns.

Discussion. At first sight, Dendrophthora coronata resembles D. apiculata and $D$. lindeniana. However, D. coronata can be readily recognized by its marked parallel 

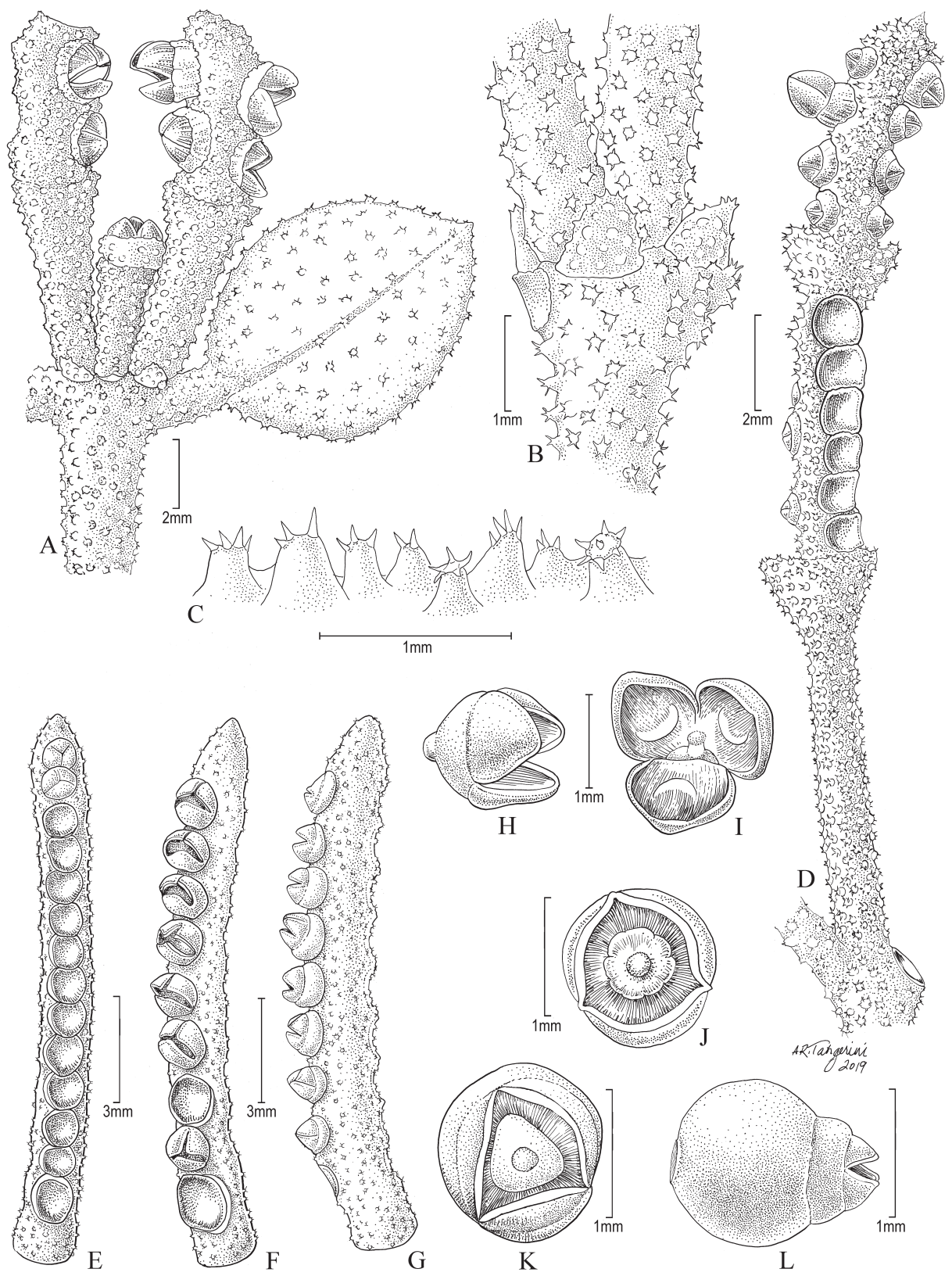

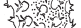

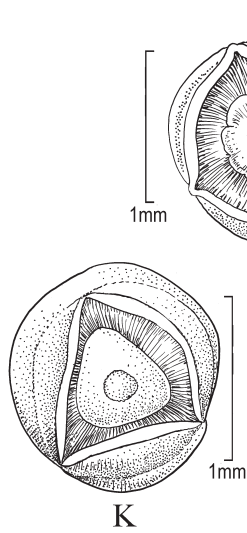

$\mathrm{D}$
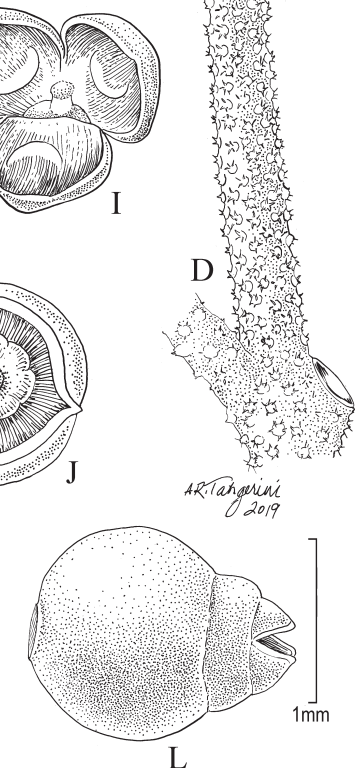

Figure 4. Dendrophthora coronata. A Leaf and terminal inflorescences B Cataphylls at the base of a node C Coroniform trichomes D Complete pistillate inflorescence E-G Segments of a pistillate inflorescence H, I Flowers with vestigial anthers J-L Mature fruits. (Source: Dorr et al. 8988, US).

striations along the stems, small, $0.5-1 \mathrm{~mm}$ long basal cataphylls, which sometimes are found $1-2 \mathrm{~cm}$ above nodes in old branches, and its dense layer of predominantly coroniform trichomes that cover the entire plant. In contrast, D. apiculata and 
Table I. Morphological characters distinguishing Dendrophthora apiculata, D.coronata, and D. lindeniana.

\begin{tabular}{|c|c|c|c|}
\hline & D. apiculata & D. coronata & D. lindeniana \\
\hline Plant height & $20-30+\mathrm{cm}$ & $30-45 \mathrm{~cm}$. & Up to $100 \mathrm{~cm}$. \\
\hline Indumentum & Entire plant sparsely papillate. & $\begin{array}{l}\text { Entire plant abundantly } \\
\text { covered with coroniform } \\
\text { trichomes. }\end{array}$ & $\begin{array}{l}\text { Entire plant abundantly } \\
\text { papillate. }\end{array}$ \\
\hline Stem & $\begin{array}{l}\text { With longitudinal striations } \\
\text { (not pronounced). }\end{array}$ & $\begin{array}{l}\text { With pronounced striations } \\
\text { (furrows). }\end{array}$ & Without striations. \\
\hline Cataphylls & $\begin{array}{c}\text { Cataphylls surrounding nodes } \\
0.2-0.5 \mathrm{~mm} \text { long; only located } \\
\text { at the base of a node. }\end{array}$ & $\begin{array}{l}\text { Cataphylls in basal branches } \\
0.5-1 \mathrm{~mm} \text { long; found } \\
1-2 \mathrm{~cm} \text { above a node. }\end{array}$ & Cataphylls not present. \\
\hline Leaf apex & $\begin{array}{c}\text { Apiculate; apiculum } 0.2- \\
0.5 \mathrm{~mm} \text { long. }\end{array}$ & Not apiculate. & Not apiculate. \\
\hline Petiole & Petiole $2-3 \mathrm{~mm}$ long. & Petiole $0.5-2 \mathrm{~mm}$ long. & Petiole up to $1 \mathrm{~mm}$ long. \\
\hline Leaf margin & Entire. & Slightly crenulate. & Entire. \\
\hline Staminate inflorescence & Triseriate. & Uniseriate. & Uniseriate. \\
\hline
\end{tabular}

D. lindeniana have stems sparsely covered by simple trichomes and lack basal cataphylls (or rarely have a few very small, $0.5 \mathrm{~mm}$ long cataphylls and then always at the nodes) (Table 1).

Additional specimens examined. Venezuela. Trujillo: Municipio Boconó, Sector El Campamento, UTM: 19368148 E, 1022056 N [9.244052N, -70.200324W], 2600, 13 Apr. 2019, S. Niño \& D. Canelón 6111 (US); Parque Nacional Guaramacal, sector Vertiente Sur, carretera al caserío Guaramacal, 2000-2750 m, Dec. 1996, B. Stergios \& A. Licata 16813 (US-00656274).

\section{Acknowledgments}

Field support in the Boconó-Trujillo region was provided by INPARQUES-Venezuela Institute, including assistance from technician engineer Marcos Hidalgo and forest ranger Ramón Caracas. Mr. Jhon Mendez elaborated the map. We are also grateful to the Smithsonian Institution for granting access to the herbarium, and to Scott Whittaker and the Microscopy Laboratory (Smithsonian Institution) for offering training and allowing us to use their equipment. Finally, we appreciate the artistic work of Alice R. Tangerini (Smithsonian Institution) who prepared splendid illustrations of the two new species.

\section{References}

Ayensu ES (1967) AerosolOT solution-An effective softener of herbarium specimens for anatomical study. Stain Technology 42(3): 155-156. https://doi.org/10.3109/10520296709115000 Cuello N, Cleef A (2011) Bosques de los Andes de Venezuela: Caso el Ramal de Guaramacal.

BioLlania Ed. Espec. 10: 74-105. 
Dorr LJ, Stergios B, Smith AR, Cuello ANL (2000) [2001] Catalogue of the vascular plants of Guaramacal National Park, Portuguesa and Trujillo states, Venezuela. Contributions from the United States National Herbarium 40: 1-155. https://www.jstor.org/stable/23493174 Global Plants JSTOR (2019) Global Plants JSTOR https://plants.jstor.org/ [accessed 12 Nov. 2019] Kuijt J (1961) A revision of Dendrophthora (Loranthaceae). Wentia 6: 1-145. https://doi. org/10.1111/j.1438-8677.1961.tb00009.x

Kuijt J (2000) An update on the genus Dendrophthora (Viscaceae). Botanische Jahrbücher für Systematik 122: 169-193.

Kuijt J (2003) Monograph of Phoradendron (Viscaceae). Systematic Botany Monographs 66: 1-643. https://doi.org/10.2307/25011253

Kuijt J (2008) Viscaceae. In: Hokche O, Berry PE, Huber O (Eds) Nuevo catálogo de la flora vascular de Venezuela. Fundación Instituto Botánico de Venezuela Dr. Tobias Lasser, Caracas, 660-665.

Kuijt J (2011) New species of neotropical Viscaceae (Dendrophthora and Phoradendron). Novon 21(4): 444-462. https://doi.org/10.3417/2010105

Kuijt J (2016) The guide of the perplexed: Essential nomenclature and iconography of the mistletoes of the New World. Victoria, BC V9B 6E3, Canada.

Nickrent DL (in press) Parasitic angiosperms: How often and how many? Taxon.

Nickrent DL, Malécot V, Vidal-Russell R, Der JP (2010) A revised classification of Santalales. Taxon 59(2): 538-558. https://doi.org/10.1002/tax.592019

Nickrent DL, Anderson F, Kuijt J (2019) Inflorescence evolution in Santalales: Integrating morphological characters and molecular phylogenetics. American Journal of Botany 106(3): 402-414. https://doi.org/10.1002/ajb2.1250

Rizzini CT (1982) Loranthaceae. In: Luces de Febres Z, Steyermark JA (Eds) Flora de Venezuela 4(2). Instituto Nacional de Parques, Dirección de Investigaciones Biológicas, Caracas, $7-316$.

Stevens PF (2020) Angiosperm Phylogeny Website. Version 14, July 2017 [and more or less continuously updated since] www.mobot.org/MOBOT/research/APweb/ [accessed 8 Jan. 2020]

Tropicos (2019) Missouri Botanical Garden. TROPICOS database, Missouri Botanical Garden, St. Louis, Missouri. http://www.tropicos.org/Name/100379976 [accessed 12 Nov. 2019] 